DEL RIO, Carlos. "El principio de trascendencia en relación con el motivo de recurso de nulidad del artículo 373 letra a) del Código Procesal Penal chileno".

Polít. crim. Vol. 13, No 25 (Julio 2018) Art. 9, pp. 322-349.

[http://www.politicacriminal.cl/Vol_13/n_25/Vol13N25A9.pdf]

\title{
El principio de trascendencia en relación con el motivo de recurso de nulidad del artículo 373 letra a) del Código Procesal Penal chileno
}

\section{The transcendence principle in relation with the ground for appeal of nullity of the article 373, letter a), of the Chilean Code of Criminal Procedure}

\author{
Carlos del Río Ferretti \\ Doctor en Derecho por la Universidad de Valencia. Profesor asociado de la Facultad de \\ Derecho Universidad Católica del Norte. \\ cdrio@ucn.cl
}

\section{Resumen:}

Este estudio se ocupa del denominado principio de trascendencia en relación con el motivo de nulidad previsto en el artículo 373 letra a) del CPP. En primer término intenta probar su aplicación desde el punto de vista normativo y jurisprudencial, ofreciendo razones precisas sobre este extremo. Seguidamente se centra en la cuestión más problemática desde el punto de vista aplicativo, como es fijar un concepto preciso de trascendencia con arreglo al cual se pueda hacer el juicio de trascendencia que deba realizar en sede de recurso de nulidad la Corte Suprema.

El artículo se hace cargo de las distintas aproximaciones desarrolladas por la Corte Suprema mediante el examen de sus principales pronunciamientos y al tiempo ofrece una visión desde la dogmática procesal. Y a partir de la combinación de ambas perspectivas de análisis se termina proponiendo un concepto ajustado y completo de lo que deba entenderse por trascendencia del vicio denunciado por medio del motivo del artículo 373 letra a) CPP.

\section{Palabras Clave:}

Principio de trascendencia, recurso de nulidad, nulidad procesal

\begin{abstract}
:
This study deals with the so-called principle of transcendence in relation to the ground of nullity provided in article 373 letter a) of the CPP. Firstly, it tries to prove its application from the normative and jurisprudential point of view, offering precise reasons on this theme. It then focuses on the most problematic issue from the point of view of application, such as setting a precise concept of transcendence according to which can be made the transcendence judgment that must be made in the annulment of the Supreme Court.

The article takes care of the different approaches developed by the Supreme Court through the examination of its main pronouncements and at the same time offers a vision from the procedural dogma. And from the combination of both perspectives, we end up proposing an adjusted and complete concept of what must be understood by transcendence of the vice denounced through the motive of article 373 letter a) CPP.
\end{abstract}


Polit. crim. Vol. 13, No 25 (Julio 2018) Art. 9, pp. 322-349.

[http://www.politicacriminal.cl/Vol_13/n_25/Vol13N25A9.pdf]

\section{Keywords:}

Trascendence Principle, Appeal for Annulment, Nullity

\section{Introducción y delimitación del objeto de análisis}

En el presente estudio nos ocuparemos de un problema dogmático bien preciso del recurso de nulidad penal, consistente en la aplicación del principio de trascendencia en relación con el motivo de la letra a) del art. 373 del CPP del recurso de nulidad.

Para este propósito atenderemos, por una parte, a la propia configuración del motivo y, por otra, a la relación que mantiene ese motivo con el denominado principio de trascendencia de la lesión denunciada por ese cauce procesal, previsto en el art. 375 del mismo cuerpo legal. El primer precepto, esto es, la letra a) del 373 dispone que se anularán el juicio oral y la sentencia «[c]uando, en cualquier etapa del procedimiento, se hubieren infringido sustancialmente derechos o garantías asegurados por la Constitución o por los tratados internacionales ratificados por Chile que se encuentren vigentes...»

La otra disposición —el art. 375- señala que «[n]o causan nulidad los errores de la sentencia recurrida que no influyeren en su parte dispositiva...»

Han sido problemáticas las comprensiones de estas dos cuestiones que están vinculadas. La lesión sustancial de los derechos y garantías en el proceso, como elemento esencial de la configuración del motivo, y la interacción de aquella con el principio de trascendencia como requisito para la invalidación.

Lo cierto es que estos problemas exigen tener presente la naturaleza de los vicios denunciables a través de un recurso de naturaleza casacional o invalidatorio. ${ }^{1}$ Como se sabe, estos se resuelven en los denominados errores in iudicando o en errores in procedendo. Esto es, en errores en la aplicación de la norma material o bien en vicios que importan la inejecución de normas que inciden en la realización del proceso.

Íntimamente vinculado a lo anterior conviene apuntar que aquellos errores no se traducen en el reproche de una misma conducta. El error in iudicando se expresa en una censura o denuncia al juicio sustantivo de fondo, en cuanto se considera que en él se ha procedido a hacer una incorrecta determinación o aplicación de la norma material aplicada para la resolución del asunto. El error in procedendo en cambio se manifiesta de otra forma, y que se suele traducir ya no en un error de juicio, sino stricto sensu en un vicio de conducta procesal (actuación o realización), y que se exterioriza en la inejecución de una norma jurídica de carácter procesal que incide o modela en abstracto la conducta debida dentro del proceso, destinadas a asegurar una inmunidad, una posición u oportunidad procesales dentro del proceso o que, siendo procesal, regula la actividad de enjuiciamiento.

\footnotetext{
${ }^{1}$ Partiendo por las notables observaciones sobre este extremo que se deben a CALAMANDREI, Piero, $L a$ casación civil, t. I, vol. I, Trad.: SENTÍS, Santiago, Buenos Aires: Editorial Bibliográfica de Argentina, 1945, pp. 63 y ss y pp. 162 y ss.
} 
DEL RIO, Carlos. "El principio de trascendencia en relación con el motivo de recurso de nulidad del artículo 373 letra a) del Código Procesal Penal chileno".

¿En cuál de estas categorías se incardina la letra a) del artículo 373 CPP? Estimamos que la mayoría de supuestos concretos que se conducen por el motivo de nulidad indicado son errores in procedendo, en los términos que hemos fijado recién. ${ }^{2}$

Con lo anterior conviene partir sentando que el literal a) del art. 373 se resuelve (en la práctica) en el reproche de errores in procedendo, esto es, en la concreta inejecución de una norma que asegura una inmunidad determinada, o supone el menoscabo de una posición procesal garantizada por aquella, o bien la pérdida o embarazo de una oportunidad procesal conferida a las partes, o que, por último, importa la inejecución de una norma que establece y garantiza las reglas formales que regulan o inciden en el propio enjuiciamiento de mérito. En nuestro concepto esta consideración es importante para la comprensión de los asuntos que indicamos con anterioridad. Vale decir, tanto para la comprensión de la sustancialidad de la infracción como para la cuestión de la trascendencia.

\section{El problema de la sustancialidad de la infracción y de la trascendencia en el motivo del artículo 373 letra a)}

\footnotetext{
${ }^{2}$ CORTEZ MATCOVICH, Gonzalo, El recurso de nulidad, Santiago: LexisNexis, 2006, pp. 146-148, parece matizar esta afirmación en tanto estima que bajo el art. 373 letra a) se pueden poner supuestos de errores in procedendo como errores in iudicando. Esta afirmación se basaría en que los vicios comprendidos en la norma citada no se limitan a hipótesis de infracción de normas de procedimiento sino también de normas que están orientadas a regular el enjuiciamiento. Con todo, este argumento no es preciso, puesto que errores in procedendo no comprenden únicamente vicios que se concretan durante la tramitación del procedimiento (antes del pronunciamiento de la sentencia), sino naturalmente cualquier error procesal, incluso aquellos que se verifican en la forma en que se debe proceder a juzgar y dictar sentencia de mérito.

Por otra parte, a menudo se afirma que es error in iudicando la infracción del deber de correlación o el vicio de dictar sentencia contra otra pasada en autoridad de cosa juzgada, o los vicios de falta de motivación o de incorrecta ponderación de la prueba. Con todo, en nuestra opinión es evidente que no son vicios in iudicando, al menos vicios in iudicando in iure. Todo vicio in iudicando in iure, vale decir, todo vicio o error en la determinación, en la interpretación o en la aplicación de norma sustantiva o material para la resolución de fondo del asunto únicamente debe ser conducido por la letra b) del artículo $373 \mathrm{CPP}$.

Otra cosa distinta es que la inejecución de norma procesal sobre la formación del mérito fáctico y el correspondiente enjuiciamiento pueda ser calificada de error in iudicando facti, categoría a la que se refiere CALAMANDREI, La casación civil, cit. nota 1, vol. III, pp. 306-308. Esta situación - salvo en los sistemas de prueba legal y tasada en que obviamente resulta equivalente a un error in iudicando in iure - suele recibir el tratamiento de un vicio in procedendo.

En fin, no desconocemos que parte de calificada doctrina critica esta forma de tipificar los motivos de casación, como hace por ejemplo NIEVA, Jordi "La enunciación de los motivos de casación en las leyes procesales", en: NIEVA, Jordi, El recurso de casación, Santiago de Chile: Abeledo Perrot, 2010, pp. 75 y ss. Este autor en lo sustantivo señala que la sistemática de separación de vicios in iudicando y vicios in procedendo plantea situaciones problemáticas de donde pueden derivarse soluciones inadecuadas. En efecto la idea que los vicios o los errores in iudicando son aquellos que inciden en la determinación, interpretación o aplicación de la norma de fondo o material para la decisión del asunto u objeto procesal, mientras que el error in procedendo sea un error o más precisamente una pura inejecución de una norma procesal que no sirve para la decisión del asunto, puede ser una forma de sistematizar inadecuada por ejemplo en los casos de infracción a las reglas de la prueba o a la infracción a las reglas de correlación, las cuales desde luego inciden en el juicio mismo o resolución, aun cuando no impliquen infracción de norma material. Otro tanto pasa con la violación de la cosa juzgada que obviamente se traduce en una decisión que se manifiesta en un exceso de poder jurisdiccional, cuando no correspondía pronunciar decisión de fondo.

Creemos sin embargo que la crítica esencial puede derivar de una comprensión inexacta o incompleta de las categorías señaladas, y que bien puede solucionarse si se tiene en cuenta lo antes consignado.
} 
Polít. crim. Vol. 13, No 25 (Julio 2018) Art. 9, pp. 322-349.

[http://www.politicacriminal.cl/Vol_13/n_25/Vol13N25A9.pdf]

El segundo punto sobre la configuración del motivo estriba en la necesidad de considerar la "infracción sustancial de derechos y garantías" y la eventual incidencia o no de aquello en la exigencia de trascendencia del art. 375 CPP (principio de trascendencia). ${ }^{3}$ El asunto es si ese elemento esencial del motivo excluye la aplicación del propio requisito o límite dispuesto en el art. 375, en tanto él mismo operaría como la exigencia de trascendencia haciendo parte del motivo mismo y de tal modo se haría completamente inaplicable el previsto en el precepto citado.

La respuesta intuitiva — en apariencia razonable - suele ser la negación prima facie del requisito de trascendencia para el motivo en cuestión, de modo que no cabría exigir que la infracción del derecho o garantía, además de sustancial, tenga así mismo «trascendencia en lo dispositivo del fallo». Nótese que esta posición ha tenido respaldo en parte de la doctrina. $^{4}$

Con independencia de su pertinencia técnica (o de lege ferenda), existen poderosos fundamentos de derecho positivo que permiten llegar a la conclusión contraria, esto es, a la ineludible aplicación del 375 en relación al motivo en cuestión.

Desde un punto de vista positivo, el legislador ubicó en el art. 375 una norma específica que con arreglo a una interpretación jurídica sistemática nos habría de llevar a la conclusión de que justamente aquel está únicamente concebido para el caso de la letra a) del art. 373, y no para los demás motivos.

Avala esta tesis, primero, la evidencia que su aplicación no es procedente para el motivo de la letra b) del artículo 373. La razón es obvia: en este motivo la trascendencia se considera un elemento del propio motivo. Así el precepto correspondiente dispone: «Procederá la declaración de nulidad de la sentencia y del juicio (...) Cuando, en el pronunciamiento de la sentencia, se hubiere hecho una errónea aplicación del derecho que hubiere influido sustancialmente en lo dispositivo del fallo». De este modo, la trascendencia es un elemento del motivo y no un requisito de la eficacia de aquel, que limita el eventual efecto invalidatorio. Así entonces el motivo del art. 375 no añade nada que ya no se exija en la configuración del propio motivo: es en principio jurídicamente inútil como mandato respecto del literal $b$ ).

Segundo, en cuanto al art. 374, vale decir, al rubro de los denominados motivos absolutos, el 375 es también inaplicable, puesto que se trata de hipótesis en donde la trascendencia de la lesión se supone o "presume" por el mismo precepto precitado. ${ }^{5}$ El propio 374 consigna

\footnotetext{
${ }^{3}$ En términos generales sobre el principio o requisito de la trascendencia: MOSQUERA RUIZ, Mario; MATURANA MIQUEL, Cristián, Los recursos procesales, Santiago de Chile: Editorial Jurídica de Chile, 2010, p. 338; HORVITZ LENNON, María Inés; LÓPEZ MASLE, Julián, Derecho procesal penal, t. II, Santiago de Chile: Editorial Jurídica de Chile, 2005, pp. 392 y ss.

${ }^{4}$ RIETOURD ALVARADO, Andrés, El recurso de nulidad en el nuevo proceso penal, Santiago de Chile: Editorial Jurídica de Chile, 2007, pp. 42 y ss., parece sostener la tesis de que el motivo del literal a) del art. 373 no queda sujeto al juicio de trascendencia, sino únicamente al juicio de sustancialidad de la infracción, y por esta razón se muestra crítico de determinada jurisprudencia de la Corte Suprema que sostiene lo contrario. También sostendría lo mismo HORVITZ / LÓPEZ Derecho procesal penal, cit. nota 3, pp. 412-416.

5 Aunque en relación con el art. 374 también cabría hacer matizaciones: vid. por ejemplo DEL RÍO FERRETTI, Carlos, El derecho al recurso y el recurso de nulidad penal, Santiago de Chile: Thomson
} 
DEL RIO, Carlos. "El principio de trascendencia en relación con el motivo de recurso de nulidad del artículo 373 letra a) del Código Procesal Penal chileno".

que cualquiera de sus hipótesis invalidará "siempre" el juicio oral y la sentencia, de modo que bien puede inferirse que los motivos absolutos son casos específicos donde el legislador "presume" o, mejor, prescinde de la trascendencia, quedando fuera entonces del alcance del 375.

La causal del literal a) del 373, contrario sensu, se opone a la técnica basada en el principio de taxatividad del 374, porque en el primer precepto el legislador establece una cláusula genérica en la cual se deben subsumir casos, en tanto se trate de supuestos concretos de comprobada trascendencia procesal, determinada caso a caso en sede judicial. En el 374 es el propio legislador quien se ocupa de señalar taxativamente los supuestos que ex ante se estiman con capacidad para lesionar un derecho o garantía y con capacidad para privar de - o afectar a una parte en- una posición, una expectativa, una oportunidad, o una inmunidad reconocida en el proceso. ${ }^{6}$

De la diferencia antes descrita se deriva un tercer argumento para confirmar la conclusión de la aplicación del requisito de trascendencia del 375 al motivo del 373 letra a). En efecto, la diferencia en cómo operan los motivos señalados incide en que el juicio de trascendencia en el caso del literal a) del 373 se determine en sede jurisdiccional, en cuanto no viene definido o supuesto ex lege. Y por esta razón se explica que frente a motivos de una misma naturaleza exista, no obstante, una regla de reparto de competencia funcional diversa, en virtud de la cual el conocimiento del motivo genérico sea sometido a la Corte Suprema, en tanto que los absolutos quedan entregados a las Cortes de Apelaciones. A la Corte Suprema se le exige la creación de criterios parejos y estables para bastantear la trascendencia de supuestos lesivos de derechos y garantías que no están tipificados en la norma, cosa que no podría conseguirse con 17 cortes distintas pronunciándose al mismo tiempo sobre aquellos casos. Esta razón no existe para los motivos absolutos en donde la corte limita su juicio a la constatación del supuesto tipificado, y por eso no se vislumbra —en este puntoinconveniente que las cortes intermedias resuelvan a su respecto.

Corolario de lo indicado - y estimando al legislador un legislador racional — habría que inferir que no pudo prever el art. 375 sino para el único motivo que no rechaza

Reuters, 2014, pp. 86-88.

${ }^{6}$ Nótese por ejemplo que en el modelo italiano la nulidad procesal está regida por el principio de taxatividad del artículo 177 del Código de Procedimiento Penal italiano (en adelante, CPPi). Supone que los casos de inobservancia de legalidad en que puede incurrir un acto y que producen nulidad están previstos en la norma legal, y en consecuencia no existe nulidad fuera de ese elenco legal de supuestos. Por esta razón, se dice, que por una parte está prohibida la aplicación analógica y, por otra, es irrelevante la acreditación del perjuicio o, mejor, del interés jurídico protegido por la forma procesal quebrantada. Vid. FONTANA, Filippo: "Commento Articolo 177" en: CORSO, Piermaria (Editor): Commento al Codice di procedura penale, Piacenza: Casa Editrice LaTribuna, pp. 527-532, 2005, pp. 531-532; GAROFOLI, Vincenzo, Istituzione di Diritto processuale, Milano: Giuffrè, 2006, pp. 63-64; TONINI, Paolo, Lineamenti di Diritto processuale penale, $3^{a} E d$., Milano: Giuffrè, 2005, pp. 105-107.

Cabe apuntar que es muy importante constatar que la idea de irrelevancia del perjuicio o de la concreta lesión del bien jurídico protegido juega y funciona muy bien si viene vinculada al principio de taxatividad. Al contrario, un sistema que no consagra este principio sino la libre declaración de la nulidad por la autoridad judicial sobre la base de cláusulas abiertas, invariablemente habrá de funcionar mejor previendo la limitación o requisito del perjuicio que actúa como temperamento a la latitud de la potestad invalidatoria del juez. Esta es una reflexión que parece oportuna cuando uno reflexiona sobre el incompleto y confuso régimen de la nulidad procesal y del recurso de nulidad. 
Polit. crim. Vol. 13, No 25 (Julio 2018) Art. 9, pp. 322-349.

[http://www.politicacriminal.cl/Vol_13/n_25/Vol13N25A9.pdf]

explícitamente su aplicación, cual es el caso de la letra a) del 373.

\section{El juicio de trascendencia del artículo 375 (en relación con la letra a) del artículo 373)}

Despejado el asunto de la aplicación de la trascendencia del art. $375^{7}$, cabe preguntarse si la norma expresa acertadamente este requisito de la eficacia invalidatoria del motivo.

En nuestro concepto la norma es muy deficiente por más de una razón. Su formulación en primer término se refiere a los «errores de la sentencia...» como si los supuestos comprendidos en la letra a) del 373 supusieran solamente errores que se verifican en la decisión de mérito - en su pronunciamiento- con exclusión de errores o vicios que tienen lugar en la secuela del procedimiento. Salvo que se entendiese que respecto de estos últimos no cabe exigir el requisito en cuestión, cosa que no obstante no tiene asidero por la naturaleza y tipo de vicio de que estamos hablando.

En seguida la norma es insatisfactoria así mismo porque el juicio de trascendencia referido en el precepto restringe su alcance o se agota en el supuesto de que el yerro tenga efectiva influencia en lo dispositivo de la sentencia, lo cual resulta inadecuado en atención al tipo de vicio a que se refiere el motivo al que se aplica. Como se ha dicho este es de carácter esencialmente procesal, y no sustancial o de fondo.

Sin ser óptima hubiese sido preferible mantener la fórmula de la limitación de la casación en la forma prevista en el art. 768 del CPC, cuando en su inciso penúltimo expresa que: “(...) el tribunal podrá desestimar el recurso de casación en la forma, si de los antecedentes aparece de manifiesto que el recurrente no ha sufrido un perjuicio reparable sólo con la invalidación del fallo o cuando el vicio no ha influido en lo dispositivo del fallo".

Esta forma de enunciar el requisito de trascendencia es desde luego más amplia, además de más armónica con el concepto de perjuicio de la nulidad procesal que se utiliza en el art. 159 del CPP, cuando señala que existe perjuicio "cuando la inobservancia de las formas procesales atenta contra las posibilidades de actuación de cualquiera de los intervinientes en el procedimiento".

Como se podrá advertir, la fórmula del 375 es estrecha en sus términos, además de inadecuada, si lo que se denuncia mediante el 373 letra a) es una inejecución de una norma procesal o de una garantía procesal o individual que incide en la forma de realización del proceso penal. Allí el perjuicio y, por tanto, la trascendencia son eminentemente procesales. Vale decir, se violenta o quebranta una inmunidad con relación al proceso, se priva o menoscaba una oportunidad procesal o se lesiona una posición o expectativa procesal, todo lo cual obviamente no presenta relación de causalidad (necesaria) con lo dispositivo de la sentencia, por más grave que haya sido tal quebrantamiento formal.

\footnotetext{
${ }^{7}$ La jurisprudencia de la Corte Suprema en términos generales y desde hace tiempo considera que sí se exige el juicio de trascendencia: entre muchas, vid. CORTE SUPREMA. 29 de octubre de 2002. Rol N 3319-2002; CORTE SUPREMA. 18 de enero de 2006. Rol N 5960-2005; CORTE SUPREMA. 31 de marzo de 2009. Rol N 502-2009; CORTE SUPREMA. 12 de octubre de 2010. Rol N 5608-2010.
} 
DEL RIO, Carlos. "El principio de trascendencia en relación con el motivo de recurso de nulidad del artículo 373 letra a) del Código Procesal Penal chileno".

Esta circunstancia es de suma importancia, puesto que un juicio de trascendencia ajustado a la letra del precepto nos llevaría a la lamentable conclusión de que una parte significativa de los casos de infracción de garantías procesales, al estar causalmente desvinculadas del contenido resolutivo de la sentencia, su infracción no se reflejará en la parte dispositiva o, al menos, no necesariamente, y ello con completa independencia de la entidad o sustancialidad de la lesión de la garantía o derecho afectado. La conclusión inevitable sería que todos esos vicios - lesiones - serían procesalmente intrascendentes y no producirían el efecto invalidatorio propio del motivo de nulidad.

Con todo lo insatisfactorio que pueda parecer esta consecuencia, la solución, sin embargo, no pasa por hacer caso omiso a la exigencia de trascendencia que se mantiene en el Código.

\section{Las formas en que la Corte Suprema ha interpretado el punto tocante a la trascendencia del vicio denunciado por vía del art. 373 letra a)}

La jurisprudencia de la Corte Suprema ha interpretado el principio de trascendencia con cierta autonomía del tenor literal del 375, en la mayoría de los casos que conoce por vía del motivo en análisis.

No obstante, aquella no es uniforme y por ello se pueden hallar diversas posiciones respecto de lo que sea el requisito de trascendencia y de cómo en definitiva se aplica como limitación a la eficacia invalidatoria del motivo.

\subsection{La posición que pretende resolver el asunto de la trascendencia aplicando la presunción de derecho de perjuicio del artículo 160 CPP}

Algunas sentencias de la Corte Suprema $^{8}{ }^{9}$ han querido resolver el problema de la determinación de la trascendencia por un camino en que parece considerarse aquella con base en la aplicación de una presunción iuris et de iure. Son las sentencias que acuden a la presunta "presunción de derecho" del art. 160 CPP, prevista para la nulidad procesal.

La premisa que sostendría esta posición consiste en que siendo la nulidad procesal un instituto unitario que comprende diversos mecanismos procesales que persiguen la invalidación de actuaciones y actos procesales de distinta especie dentro del proceso, ellos se rigen (o deben regirse) por principios y reglas comunes que deban ser aplicados e interpretados armónicamente. ${ }^{10}$ De este razonamiento se extrae la conclusión que bien cabe aplicar la "presunción de derecho" del art. 160 del incidente de nulidad procesal al caso del

\footnotetext{
${ }^{8}$ CORTE SUPREMA. 13 de agosto de 2008. Rol N 3198-2008; CORTE SUPREMA. 12 de noviembre de 2008. Rol $N^{\circ}$ 4954-2008; CORTE SUPREMA. 3 de noviembre de 2009. Rol $\mathrm{N}^{\circ}$ 5658-2009; CORTE SUPREMA. 4 de noviembre de 2009. Rol N 6165-2009. También en esta misma tesis los votos de minoría de ministro Carlos Künsemuller, en CORTE SUPREMA. 30 de enero de 2008. Rol N 2377-2007; y, CORTE SUPREMA. 30 de enero de 2008. Rol N 6631-2007.

9 También parece sostener este criterio OTERO LATHROP, Miguel, La nulidad procesal civil, penal, y de derecho público, $2^{a} E d$., Santiago de Chile: Editorial Jurídica de Chile, 2010, pp. 148-149 y 175-180.

${ }^{10}$ Como hemos apuntado la jurisprudencia que avala esta tesis parte de esta premisa que es un lugar común en nuestra dogmática procesal. Vid. por todos SALAS VIVALDI, Julio, Los incidentes y en especial el de nulidad en el proceso civil, penal y laboral, $7^{a}$ Ed., Santiago de Chile: Editorial Jurídica de Chile, 2000; OTERO, La nulidad procesal..., cit. nota 9, pp. 85 y ss. y 201 y ss.
} 
Polit. crim. Vol. 13, No 25 (Julio 2018) Art. 9, pp. 322-349.

[http://www.politicacriminal.cl/Vol_13/n_25/Vol13N25A9.pdf]

motivo del 373 letra a), en tanto ambos preceptos tratan la nulidad en supuestos de infracción de derechos y garantías fundamentales. ${ }^{11}$

La Corte Suprema, en sentencia de 12 de noviembre de 2008, acoge esta posición en los siguientes términos:

"Que la disposición del artículo 373 letra a) del Código Procesal Penal, exige que la infracción de derechos o garantías sea sustancial.

"Pudiera pensarse que se ignora en este caso si la infracción cometida es o no sustancial, porque no es posible determinar a priori si la apelación del Ministerio Público prosperará o no o, si como sostuvo el representante del ente persecutor y ya se analizó, bastaba con que el Tribunal Oral en lo Penal desechara algunos de esos medios probatorios.

"Sin embargo, este concepto de sustancialidad debe ser abordado también desde la óptica constitucional, toda vez que se trata de la tutela de los derechos que ella misma garantiza, o que reconocen los tratados internacionales.

"Valga aquí, en consecuencia, tener a la vista la prescripción normativa del artículo 19 $\mathrm{N}^{\mathrm{o}} 26$ de la Constitución Política, que garantiza a los ciudadanos, la seguridad de que los preceptos legales que por mandato de la Constitución regulen o complementen las garantías que ésta establece o que las limiten en los casos en que ella lo autoriza, no podrán afectar los derechos en su esencia, ni imponer condiciones, tributos o requisitos que impidan su libre ejercicio.

"Establecido el derecho a la defensa y al debido proceso en el articulado de la Constitución Política, esta disposición recién transcrita es la que impide coartar el derecho mencionado en su esencia, que es precisamente lo que ha ocurrido en estos autos.

"Esa norma tiene su correlato en el artículo 160 del Código Procesal Penal, que presume de derecho la existencia del perjuicio, cuando la infracción ha impedido el pleno ejercicio de las garantías y de los derechos reconocidos en la Constitución, o en las demás leyes de la República.

"En el caso en estudio, al procederse como lo hizo la Corte de Apelaciones de Puerto Montt, que adoptó su decisión en base a antecedentes que no le fueron entregados por las partes y sin permitirles a ellas particularmente a la defensa en este caso poder ejercer los derechos que la Constitución Política les garantiza, limitó a tal punto los derechos involucrados, que la infracción resultó ser sustancial, en los términos que prescribe el artículo 373 letra a) del Código Procesal Penal." 12

Otro ejemplo se encuentra en un fallo de 3 de noviembre de 2009, de la Corte Suprema, que ratifica la aplicación de la "presunción de derecho" del art. 160, en los siguientes términos:

\footnotetext{
${ }^{11}$ OTERO, La nulidad procesal..., cit. nota 9, pp. 148 y ss., aunque no sea preciso en este sentido aquello se infiere de su exposición y de la cita de jurisprudencia en apoyo a sus explicaciones, que hacen exacta aplicación del art. 160 en relación con el art. 373 letra a).

${ }^{12}$ CS. Rol N 4954-2008. Considerando Undécimo.
} 
DEL RIO, Carlos. "El principio de trascendencia en relación con el motivo de recurso de nulidad del artículo 373 letra a) del Código Procesal Penal chileno".

"Que, en conclusión, la actuación del Juez del Tribunal de Garantía de Iquique, don Frederick Arturo Roco Alvarado que ha sido reprochada en estos autos, puso al imputado en una situación desventajosa o desfavorable, ya que al incorporar de oficio antecedentes que no fueron hechos valer por el ente persecutor y comprometer su decisión con el interés de este último, le ha impedido al enjuiciado ejercer sus derechos como interviniente en un plano de igualdad frente a su oponente y consecuente con ello, le ha imposibilitado obtener una decisión jurisdiccional favorable, experimentando así el perjuicio trascendente requerido para la procedencia de la nulidad procesal.

"En todo caso, de acuerdo al artículo 160 del Código Procesal Penal se presume de derecho la existencia del perjuicio cuando la infracción hubiere impedido el pleno ejercicio de las garantías y de los derechos reconocidos en la Constitución, o en la demás leyes de la República, tal como acontece en este caso, en que se ha quebrantado la garantía del debido proceso y en particular, el derecho a ser juzgado por un tribunal imparcial, cuya consagración constitucional y legal ya fue explicitada en el motivo sexto de este fallo, siendo forzoso concluir que la sentencia recaída en el procedimiento simplificado en análisis es nula." ${ }^{13}$

Un tercer caso en que se ha acogido este criterio se halla en sentencia de 4 de noviembre de 2009, de la Corte Suprema. Apunta:

"Que el artículo 373, letra a) del Código Procesal Penal exige que el atropello de derechos o garantías sea sustancial, lo que encuentra su correlato en el artículo 160 del Código Procesal Penal, cuando presume de derecho la existencia del perjuicio, si la anomalía ha impedido el pleno ejercicio de las garantías y de los derechos reconocidos en la Carta Magna, o en las demás leyes de la República."14

"Que el vicio constatado aparece revestido de la relevancia necesaria para acoger el remedio procesal propuesto, precisamente porque impidió el pleno ejercicio del derecho a defensa amparado en el debido proceso, razón por la cual, se invalidará el juicio reponiéndose el procedimiento al estado de celebrarse una nueva audiencia de juicio oral ante tribunal no inhabilitado que corresponda." 15

Una crítica a esta posición nos obliga a consignar que la denominada presunción de derecho del art. 160 es una cláusula que no consagra en sus términos una presunción iuris et de iure no obstante que así lo declare. Basta leer el precepto para advertir que se trata de otra cosa. Nótese que dice presumir lo que ha de concurrir para que opere la presunción. En palabras llanas, no presume sino que fija un criterio normativo para determinar cuándo se entenderá que hay perjuicio. Así, señala que hay tal cuando la infracción de los derechos o garantías haya impedido el pleno ejercicio de aquellos.

Aun cuando la fórmula legal es equívoca, cabe inferir que el perjuicio (trascendencia) existe en tanto la infracción implique una merma del "pleno ejercicio" de un derecho o garantía. Ahora bien, la utilización del giro "pleno ejercicio" da cuenta de que se trata de la verificación de una pérdida o merma concreta acaecida en el proceso. De este modo el

\footnotetext{
${ }^{13}$ CS. Rol N ${ }^{\circ}$ 5658-2009. Considerando Duodécimo.

${ }^{14}$ CS. Rol N 6165-2009. Considerando Decimoquinto.

${ }^{15}$ CS. Rol N 6165-2009. Considerando Decimosexto.
} 
Polít. crim. Vol. 13, No 25 (Julio 2018) Art. 9, pp. 322-349.

[http://www.politicacriminal.cl/Vol_13/n_25/Vol13N25A9.pdf]

criterio normativo censura con la nulidad cualquier vicio o irregularidad que importe infracción a un derecho o garantía, siempre que se traduzca en la merma concreta de una oportunidad o inmunidad, situación o expectativa procesal, y con tal que sea perceptible y comprobable y que en consecuencia pueda considerarse un detrimento - por mínimo que sea- al pleno, completo o absoluto aprovechamiento o goce de aquellas. ${ }^{16}$

En nuestra opinión, sin embargo, el art. 160 estimado como criterio o estándar normativo para medir el perjuicio procesal no sirve para reinterpretar el principio de trascendencia del art. 375. Hay una diferencia fundamental en la que no se repara a primera vista entre el perjuicio de la nulidad procesal y la trascendencia del recurso de nulidad, consistente en que aquella se predica respecto de una actuación o acto procesal que remite a una oportunidad o una posición procesales de las partes en la secuela del proceso pendiente, que conviene preservar de cualquier detrimento comprobable, de modo que en este caso el principio de conservación ${ }^{17}$ de los actos procesales tiene un vigor muy disminuido, si se tiene en cuenta el citado art. 160 en relación con el art. 163, que le confiere poderes de oficio al juez para declarar la nulidad respecto de aquel supuesto. En cambio, la trascendencia para determinar si procede la invalidación de la sentencia está referida a la propia resolución de mérito tras la completa sustanciación del procedimiento, y se resuelve en determinar si ella se ha visto o se ha podido llegar a ver condicionada por el vicio que se denuncia. De este modo puede considerarse que el principio de validez formal de la sentencia mantiene su fuerza esencial al menos respecto del art. 373 letra a). ${ }^{18}$

\footnotetext{
${ }^{16}$ En nuestro concepto uno de los errores del diseño del régimen de nulidad procesal es que declara "presumir de Derecho" el perjuicio, no obstante que es evidente que no es exactamente así. En estricto rigor técnico lo que cabe es prescindir de la exigencia de perjuicio o, mejor dicho, de la necesidad concreta de comprobación del perjuicio, siendo este excepcionalmente irrelevante de cara a la invalidación. En estos términos podría llegar a operar correctamente si se articulase bien con el principio de taxatividad, lo que ciertamente excluye la pura existencia de una sola cláusula abierta, como es el art. $160 \mathrm{CPP}$, que pretende ser lo que en doctrina se llama un caso abierto de nulidad absoluta.

Un régimen como este sí que tendría perfecta consonancia con el régimen del recurso de nulidad y en particular con los motivos absolutos de nulidad, en donde se indican taxativamente los casos donde el perjuicio o trascendencia del vicio es irrelevante de cara a la invalidación. Por eso la norma del 374 indica "El juicio y la sentencia serán siempre invalidados", dando a entender que la nulidad tiene lugar con independencia del perjuicio, que deviene irrelevante del punto jurídico procesal.

Un ejemplo de un régimen mejor concebido es, como ya se ha dicho, el modelo italiano regido por el principio de taxatividad del artículo $177 \mathrm{CPPi}$, en el cual, dado este principio, si se puede aplicar correctamente la regla de la irrelevancia del perjuicio para el conjunto de casos tipificados por el legislador. Vid. FONTANA, "Commento Articolo 177", cit, nota 6, pp. 531-532; GAROFOLI, Istituzione di Diritto processuale, cit, nota 6, pp. 63-64; TONINI, Lineamenti di Diritto ..., cit, nota 6, pp. 105-107.

${ }^{17}$ El principio de conservación de los actos procesales ha sido considerado muy relevante en la teoría de la nulidad de los actos procesales, ciertamente queda disminuido por la razón indicada en el texto.

Dentro de la concepción tradicional de nuestra jurisprudencia sobre este principio, puede consultarse la sentencia de la CORTE DE APELACIONES DE SANTIAGO. 05 de abril de 1999. Rol N 2119-1995. GJ, 226, pp. 86 y ss. Este asunto también está citado y analizado por CARRASCO POBLETE, Jaime, "La nulidad procesal como técnica protectora de los derechos y garantías de las partes en el Derecho procesal chileno", Revista de Derecho Universidad Católica del Norte, n. 18.1 (2011), pp. 49-84, p. 69, en: http://revistaderecho.ucn.cl/index.php/rducn/article/view/115/115 [visitado el 06.06.2017].

${ }_{18}$ Nótese que la fuerza del principio de validez formal de la sentencia está especialmente subrayada en la teoría de los recursos de naturaleza casacional, en este siempre se parte del principio en cuestión, lo cual habrá de tenerse en cuenta para interpretar lo que en nuestro derecho se denomina principio de trascendencia.
} 
DEL RIO, Carlos. "El principio de trascendencia en relación con el motivo de recurso de nulidad del artículo 373 letra a) del Código Procesal Penal chileno".

\subsection{La posición mayoritaria que no separa con claridad (confunde) la trascendencia con la infracción sustancial del motivo}

Segunda posición: la Corte en la mayoría de sus fallos - cuando intenta delimitar y explicar el principio de trascendencia- no separa o distingue este principio de la sustancialidad de la infracción del derecho o garantía amagados por el vicio procesal que se denuncia. Son muchísimos los pronunciamientos donde una y otra cosas son tratadas indistintamente o como sinónimos ${ }^{19}{ }^{20}$, lo que en nuestro concepto es un error porque confunde conceptos que son distintos.

Encontramos versiones de esta posición que con matices de estilo dicen al cabo más o menos lo mismo. Por ejemplo, en sentencia de 31 de diciembre de 2012, de la Corte Suprema, se lee:

"Que, asimismo se ha señalado que el referido arbitrio debe entenderse regido por los mismos principios y reglas generales que gobiernan la nulidad procesal, por consiguiente para su procedencia deben concurrir los presupuestos básicos de éstas, entre los cuales se encuentra el llamado 'principio de trascendencia' que, por lo demás, recoge el artículo 375 del Código Procesal Penal, en virtud del cual la transgresión que funde un recurso de la naturaleza como el de la especie, debe constituir un atentado de tal entidad que importe un perjuicio al litigante afectado que conduzca a la ineficacia de la garantía, resultando de ello un desconocimiento del núcleo esencial de ésta.

"En otras palabras, se requiere que el vicio sea sustancial, trascendente, de importancia o gravedad, de suerte que el defecto entrabe, limite o elimine el derecho preterido." 21

Una variante de lo mismo se observa en la sentencia de 30 de enero de 2008 , de la Corte Suprema, que al respecto señala:

"El recurso de nulidad ha sido considerado entre nosotros como el corolario de la consagración del régimen de nulidad procesal que en nuevo código se contempla (Alex

Por todos, vid. la obra clásica de CALAMANDREI, La casación civil, cit. nota 1, T. I, vol. I, pp. 175-176, y en vol. III, pp. 343 y ss.; también vid. MORÓN PALOMINO, Manuel, La nulidad en el proceso civil español, Barcelona: Editorial AHR, 1957, pp. 26 y ss.; ROSENBERG, Leo, Tratado de Derecho procesal civil, t. I, Trad.: ROMERA VERA, Ángela, Buenos Aires: Ejea, 1955, pp. 438 y ss, parece partir de este mismo principio en sus explicaciones sobre los actos procesales defectuoso.

${ }^{19} \mathrm{Vid}$. por ejemplo CORTE SUPREMA. 19 de mayo de 2003. Rol No 1124-2003; CORTE SUPREMA. 17 de enero de 2005. Rol $\mathrm{N}^{\circ}$ 5444-2004; CORTE SUPREMA. 10 de agosto de 2005. Rol $\mathrm{N}^{\circ}$ 2592-2005; CORTE SUPREMA. 23 de septiembre de 2005. Rol N 3297-2005; CS. Rol N ${ }^{\circ}$ 5960-2005; CORTE SUPREMA. 10 de mayo de 2006. Rol N 897-2006; CS. Rol N 6631-2007; CS. Rol N 4954-2008; CORTE SUPREMA. 21 de octubre de 2009. Rol N ${ }^{\circ}$ 5213-2009; CORTE SUPREMA. 16 de agosto de 2010. Rol $\mathrm{N}^{\circ}$ 3615-2010; CORTE SUPREMA. 31 de diciembre de 2012. Rol No 7913-2012; CORTE SUPREMA. 26 de febrero de 2014. Rol N ${ }^{\circ}$ 556-2014; CORTE SUPREMA. 16 de junio de 2015. Rol N ${ }^{\circ}$ 5851-2015; CORTE SUPREMA. 18 de julio de 2016. Rol N ${ }^{\circ} 31025-2016$; CORTE SUPREMA. 28 de noviembre de 2016. Rol $\mathrm{N}^{\circ} 76424-$ 2016.

${ }^{20}$ Una parte de la doctrina también avala esta posición: vid. DUCE JULIO, Mauricio; RIEGO RAMÍREZ, Cristián, Proceso penal, Santiago de Chile: Editorial Jurídica de Chile, 2007, pp. 516-520, y RIETOURD, El recurso de nulidad ..., cit. nota 4, pp. 42-44, y específicamente nota 27.

${ }^{21}$ CS. Rol N ${ }^{\circ} 7913-2012$. Considerando Séptimo. 
Polit. crim. Vol. 13, No 25 (Julio 2018) Art. 9, pp. 322-349.

[http://www.politicacriminal.cl/Vol_13/n_25/Vol13N25A9.pdf]

Carocca, Nuevo proceso penal, Editorial Conosur, 2000, pág. 318).

"Así, dada la estrecha relación existente entre la nulidad procesal y el recurso de nulidad, resulta atendible hacer algunas consideraciones sobre el sistema de la nulidad procesal como sanción legal, contenido en el Código Procesal Penal.

"El principio de trascendencia exige que para anular un acto procesal deba acreditarse un perjuicio para algún interviniente.

"En otras palabras, la desviación de las formas debe tener trascendencia sobre las garantías esenciales de la defensa en juicio (Couture, cit., por Horvitz, op. Cit. pág. 393).

"A su turno Tavolari expresa que si no se reclama un perjuicio resultante precisamente de la inobservancia de las formas procesales, que ha de consistir en concreta indefensión, de no probarse ese perjuicio, no procede emitir una declaración de nulidad (Raúl Tavolari, El proceso en acción, Editorial Libromar Ltda, 2000,pág. 264).

"El artículo 159 del Código del ramo declara que existe perjuicio cuando la inobservancia de las formas procesales atenta contra las posibilidades de actuación de cualquiera de los intervinientes en el procedimiento.

"El precepto siguiente presume de derecho la existencia de perjuicio si la infracción hubiere impedido el pleno ejercicio de las garantías y derechos reconocidos en la Constitución, o en las demás leyes de la república.

"El agravio a la garantía del debido proceso debe ser real, en cuanto perjudique efectivamente los derechos procesales de la parte. Esto es, entrabe, limite o elimine su derecho constitucional al debido proceso (Miguel Otero, Código Procesal Penal, LexisNexis Conosur, 2002, pág. 109). Son las posibilidades de actuación de cualquiera de los intervinientes en el juicio las que deben verse efectivamente menoscabadas o entrabadas para que pueda configurarse el perjuicio sin el cual no puede haber nulidad.

“Además, la infracción producida a los intereses del interviniente debe ser sustancial, estos es, trascendente, de mucha importancia o gravedad, de tal modo que el defecto sea, en definitiva, insalvablemente ineficaz frente al derecho constitucional del debido proceso (SCS, rol 3319-02, Revista Procesal Penal n 4, pág. 41)."22

También se repite a menudo en diversas sentencias un considerando breve y manifiestamente tautológico. Así, la Corte Suprema señala:

"Que, sin embargo, esta Corte también ha resuelto uniformemente que el agravio a la garantía del debido proceso debe ser real, en cuanto perjudique efectivamente los derechos procesales de parte, esto es, que entraba, limite o elimine su derecho constitucional al debido proceso. Asimismo, se ha dicho que la infracción producida a los intereses del interviniente debe ser sustancial, trascendente, de gravedad, de tal modo que el defecto sea, en definitiva insalvable frente al derecho constitucional del debido proceso, por cuanto la nulidad que se pretende, en tanto constituye una sanción legal, supone un acto viciado y una desviación de las formas de trascendencia sobre las

${ }^{22}$ CS. Rol N 6631-2007. Considerando Octavo. 
DEL RIO, Carlos. "El principio de trascendencia en relación con el motivo de recurso de nulidad del artículo 373 letra a) del Código Procesal Penal chileno".

garantías esenciales de una parte en el juicio, en términos que se atenta contra las posibilidades de actuación de cualquiera de los intervinientes en el procedimiento (SCS 2866-2013; 4909-2013; 21408-2014; 1323-2015, entre otras)."23

Últimamente esta redacción aparece de nuevo en la sentencia de 28 de noviembre de 2016, de la Corte Suprema. ${ }^{24}$

En cualquiera de estas variantes se puede advertir que el análisis que se hace de la trascendencia no puede distinguirse con claridad del carácter sustancial de la infracción en cuanto elemento que hace parte del motivo. Prima la idea que la trascendencia es algo que remite a la gravedad o al carácter sustancial de la infracción, y por eso en definitiva son redacciones que en cierta medida son circulares, y trasuntan falta de claridad de que aquellos elementos son cosas distintas y que requieren de un tratamiento diferenciado.

Lo que se apunta, esto es, la necesidad de distinguir el carácter sustancial de la lesión, como elemento del motivo del recurso, de lo que es el principio de trascendencia, como requisito de la eficacia invalidatoria de aquel, se puede observar en los casos tratados, por ejemplo, en las sentencias de 18 de julio $^{25}$ y de 28 de noviembre de $2016^{26}$, de la Corte Suprema. Estas se refieren a la infracción legal del deber de registro de las diligencias de investigación que pesa sobre el Ministerio Público, circunstancia que no obstante estar claramente acreditada que se verificó en cada uno de los casos, se estimó que dicha infracción al proceso legalmente tramitado, sin embargo, no se tradujo en una concreta indefensión para los imputados en tanto pudieron conocer por otras vías - y de forma oportuna- aquellas diligencias investigativas no registradas. Hay aquí un ejemplo específico de cómo se puede ponderar en concreto la indefensión, que en la especie aparece íntimamente vinculado a la idea de la consecución del fin protegido por la norma que sanciona el vicio de nulidad $^{27}$.

Se observa que aquí el motivo está perfectamente configurado, puesto que la falta de registro es una omisión que remite al núcleo del derecho a conocer oportunamente los antecedentes de la investigación que pueden acabar sustentando una acusación y la mantención de la pretensión penal en el juicio oral. Lo que pasa es que en los casos concretos tal infracción ha carecido de trascendencia, en tanto en los hechos por razones específicas que se señalan con precisión no se acabó verificando la indefensión concreta o material que exige esta.

El carácter de sustancial de la infracción es un elemento abstracto del motivo, mientras que la trascendencia del vicio es un criterio o estándar concreto que se aplica al caso específico que se formula. Para que se entienda, la falta de registro desde luego que es una infracción

\footnotetext{
${ }^{23}$ CS. Rol N ${ }^{\circ} 31025-2016$. Considerando Quinto.

${ }^{24}$ CS. Rol N ${ }^{\circ} 76424-2016$.

${ }^{25}$ CS. Rol No $31025-2016$.

${ }^{26}$ CS. Rol No 76424-2016.

${ }^{27}$ Nos parece que aquí hay un notorio paralelismo con lo que acontece en Derecho italiano, y el tratamiento de la sanatoria de la nulidad procesal del art. $183 \mathrm{CPPi}$, en la parte que consagra dicha sanatoria del vicio cuando, no obstante, se alcanza el fin protegido por la norma. Aquí se expresa con claridad la finalidad protectora de la nulidad procesal, lo cual debe ser considerado en la interpretación íntegra del instituto jurídico. Vid. FONTANA, "Commento Articolo 177", cit, nota 6, p. 559.
} 
Polit. crim. Vol. 13, No 25 (Julio 2018) Art. 9, pp. 322-349.

[http://www.politicacriminal.cl/Vol_13/n_25/Vol13N25A9.pdf]

sustancial al derecho a conocer oportunamente los antecedentes de la investigación, en tanto está referida al núcleo de ese derecho. Pero seguidamente, caso a caso, habrá de medirse si esa infracción se concretó en los hechos en una concreta indefensión, y eso va a depender de si se pudo o no ejercer un derecho o aprovechar una oportunidad. Esta segunda parte es el juicio de trascendencia, que es un juicio concreto que hay que distinguir de la configuración abstracta del motivo, y que por eso tiene lugar en el examen de fondo respecto a la eficacia invalidatoria del vicio.

\subsection{Tercera posición de la Corte Suprema sobre el principio de trascendencia}

Una tercera posición que aparece reflejada con cierta claridad conceptual en la jurisprudencia de la Corte sobre lo que sea la trascendencia del recurso se puede encontrar en pronunciamientos que se hacen cargo de vicios que están referidos a la aportación o formación de las pruebas, o a cuestiones de ilicitud de las mismas. Vale decir, a cuestiones que hacen a la formación del mérito de la causa.

La jurisprudencia de la CS vislumbra que en este tipo de vicios hace falta adaptar el juicio de trascendencia en el recurso de nulidad, en cuanto no se presenta del mismo modo que en vicios procesales que no empalman directamente o que no están vinculados con la formación del mérito del proceso, y que no reflejan en el juicio fáctico. ${ }^{28}$

Un pronunciamiento en que aparece clara la posición que nos ocupa es el contenido en la sentencia de 28 de julio de 2016, de la Corte Suprema ${ }^{29}{ }^{30}$, aunque antes de este se habían resueltos casos con criterios que están en la línea de lo que se explicará, sobre todo con relación a situaciones de ilicitud de prueba (según se verá más adelante).

En aquella decisión se esboza una forma de concebir la trascendencia del vicio denunciado —en cuanto límite de la invalidación - distinto de los precedentes, puesto que no se centra ni en el argumento de la sustancialidad de la lesión, ni en la fórmula literal del art. 375 (referida a la influencia en lo dispositivo del fallo). La sentencia propone que tal trascendencia deba traducirse en la capacidad ("virtualidad") del vicio para influir en lo dispositivo del fallo. ${ }^{31}$

El fallo trata un caso de exclusión de prueba de la acusada, que incide claramente en la formación del mérito del proceso, y apunta lo siguiente:

"Que para definir la relevancia o incidencia en el pronunciamiento atacado de la prueba excluida, resulta indispensable entonces examinar si tiene la 'virtualidad', es decir, la cualidad o propiedad para producir el efecto aunque no lo produzca, de alterar

\footnotetext{
${ }^{28}$ Una lectura estimulante para comprender las diferencias que pueden trazarse en la materia es la clásica monografía de STEIN, Friedrich, El conocimiento privado del juez, Trad.: DE LA OLIVA SANTOS, Andrés, Pamplona: Ediciones Universidad de Navarra, 1973, pp. 138-184, cuando intenta explicar las posibilidades de control casacional y sus límites, con relación a la prueba y el consecuente juicio de hecho.

${ }^{29}$ CS. Rol No 3552-2016.

${ }^{30}$ El mismo criterio en DEL RÍO, El derecho al recurso ..., cit. nota 5, pp. 84-88.

${ }^{31} \mathrm{Vid}$. el paralelismo de un argumento como este con el desarrollado en el sistema italiano en el que se habla de la decisividad del vicio de motivación del juicio fáctico. Por todos, NAPPI, Aniello, Il sindacato di legittimità nei giudizi civili e penali di cassazione, Torino: Giappichelli, 2006, pp. 199-204.
} 
DEL RIO, Carlos. "El principio de trascendencia en relación con el motivo de recurso de nulidad del artículo 373 letra a) del Código Procesal Penal chileno".

lo decidido por los jueces de la instancia, ya sea porque su consideración podría haber conducido a la absolución del imputado, al impedir dicha probanza alcanzar convicción más allá de toda duda razonable sobre la perpetración de los hechos imputados o sobre la participación de los hechos imputados o sobre la participación del encartado en la forma planteada en la acusación, o hubiese permitido demostrar hechos o circunstancias que configuran una causal de justificación, de inculpabilidad, una excusa legal absolutoria, o un motivo de extinción de responsabilidad penal, etc; o, en cambio, porque hubiese conducido a imponer una pena inferior al sentenciado, al permitir acreditar mediante ella los elementos de una circunstancia privilegiante o atenuante, o de un estado de desarrollo del delito imperfecto o de una participación sancionada con menor pena que la autoría.

"Sopesar si en definitiva la prueba excluida conduce o no a acreditar o demostrar las circunstancias referidas, es una cuestión privativa de los jueces de la instancia, sin embargo, el principio de trascendencia obsta anular juicio y sus consecuentes sentencias por una errónea exclusión de prueba, si ésta ni siquiera ostentaba la virtualidad de alterar la decisión impugnada." 32

Un poco más adelante, la sentencia con base en este criterio se pronuncia sobre la trascendencia del motivo, referido a grabaciones excluidas como prueba a la defensa del condenado:

“(...) Como se advierte, principalmente de lo expuesto al explicar el perjuicio causado a su parte por la infracción denunciada, el recurso postula que la prueba excluida tiene la virtualidad de conducir a la absolución del acusado, pero no ilustra de modo alguno, ni siquiera someramente, de qué modo se habría llegado a ese veredicto. En efecto, no precisa el arbitrio si los hechos o dichos captados permiten demostrar que el acusado no 'agredió con golpes de pie en la mano al funcionario de carabineros' como lo establece el fallo, lo cual, por lo demás iría en contra de lo declarado en el juicio por el propio encartado al referir que al intentar sacarle los carabineros sus zapatillas, se puso a dar patadas, circunstancias en que se produjo la lesión, según se consigna en el considerando $4^{\circ}$. Tampoco el recurso aclara si, en su parecer, la agresión del acusado al carabinero está cubierta por alguna causal de justificación, como legítima defensa u otra excluyente de la antijuridicidad, o por motivos de inexigibilidad de otra conducta. En este punto debe repararse en que el supuesto contenido en el audio, ateniéndose por las razones ya expuestas a la descripción que del mismo hace quien lo grabó, ni siquiera permitiría esclarecer la dinámica o sucesión de los hechos, es decir, no sirve para dilucidar si el acusado agrede al carabinero con motivo u ocasión del ataque previamente iniciado por éste y sus acompañantes de manera inmotivada e injustificada, o si éstos responden a una agresión previa, igualmente inmotivada e injustificada, pero del imputado, caso este último que ameritaría la persecución de los funcionarios policiales para determinar su responsabilidad administrativa y penal, pero no conllevaría necesariamente la exclusión de responsabilidad penal del acusado por las lesiones causadas." 33

Este concepto de trascendencia que, como se dijo, se centra en la capacidad del vicio denunciado para incidir en lo dispositivo del fallo, resulta ser un criterio plausible cuando

\footnotetext{
${ }^{32}$ CS. Rol N ${ }^{\circ} 35552-2016$. Considerando Séptimo.
}

${ }^{33}$ CS. Rol No 35552-2016. Considerando Noveno. 
Polit. crim. Vol. 13, No 25 (Julio 2018) Art. 9, pp. 322-349.

[http://www.politicacriminal.cl/Vol_13/n_25/Vol13N25A9.pdf]

las hipótesis están referidas a la configuración del material probatorio utilizado para la adopción de la decisión de mérito. Por esta razón la Corte Suprema a menudo de forma más o menos intuitiva ha procedido con un rasero de este tipo para evaluar por ejemplo la concurrencia del motivo del 373 letra a) en supuestos de prueba ilícita practicada en juicio oral.

Nótese que un criterio semejante podría utilizarse en supuestos de injusta admisión de una prueba teñida de ilicitud o en la injusta privación de la práctica de un medio de prueba. A este respecto conviene tener presente que incluso STEIN, considera que el límite y la posibilidad del control de casación sobre la fijación de los hechos en la instancia viene marcado por el respeto de las normas procesales que rigen su determinación. En otras palabras las posibilidades (limitadas) de control sobre este extremo están referidas siempre a la infracción o quebrantamiento de una norma procesal que remite a la forma de establecimiento del juicio de hecho. ${ }^{34}$

\section{El caso de la prueba ilícita con relación al juicio de trascendencia del artículo 373 letra a)}

Un rendimiento específico de esta última noción jurisprudencial de trascendencia del vicio puede encontrarse en sentencias que se han pronunciado respecto de supuestos de prueba ilícita practicada en juicio. En este caso la trascendencia estimada como la capacidad o potencialidad para incidir en el juicio de mérito se resuelve en determinar si aquella resulta en sostén de la sentencia condenatoria, de modo que de haber sido excluida - como correspondía - el juez de mérito no habría dispuesto de material probatorio incriminatorio sobre el cual fundar la condena. Este criterio aparece en múltiples pronunciamientos de la Corte Suprema. ${ }^{35}$

El supuesto que se plantea surge ante la Corte Suprema con ocasión del conocimiento y decisión de motivos de nulidad del art. 373 letra a). A nuestro juicio la lesión que aquí se produce con más frecuencia es a la garantía procesal de la presunción de inocencia ${ }^{36}$, entendida como regla probatoria que impone a la acusación la carga de realizar una actividad probatoria al menos mínima, que importe la aportación de prueba objetivamente incriminatoria y válida. Pero, al mismo tiempo, habrá con frecuencia una lesión de un

\footnotetext{
${ }^{34}$ STEIN, El conocimiento privado..., cit. nota 18, pp. 138-184.

35 Así en CS. 19 de mayo de 2003. Rol N 1124-2003; CS. 27 de abril de 2004. Rol N 992-2004; CS. 2 de junio de 2004. Rol 1359-2004; CS. 17 de enero de 2005. Rol N 5444-2004; CS. 10 de agosto de 2005. Rol $\mathrm{N}^{\circ}$ 2592-2005; CS. 23 de septiembre de 2005. Rol N 3297-2005; CS. 10 de mayo de 2006. Rol N 897-2006; CS. 21 de octubre de 2009. Rol N 5213-2009; CS. 31 de diciembre de 2012. Rol N ${ }^{\circ}$ 7913-2012; CS. 20 de diciembre de 2012. Rol N 8007-2012; CS. 22 de abril de 2013. Rol N ${ }^{\circ} 1179-2013$.

${ }^{36}$ Vid. VEGAS TORRES, Jaime, Presunción de inocencia y prueba en el proceso penal, Madrid: La Ley, 1993, 414 pp. Sobre la prueba ilícita en general, sugerimos las siguientes lecturas: MARTÍNEZ GARCÍA, Elena, Eficacia de la prueba ilícita en el proceso penal, Valencia: Tirant lo Blanch, 2003, 237 pp.; HERNÁNDEZ BASUALTO, Héctor, La exclusión de la prueba ilícita en el nuevo proceso penal chileno, Santiago de Chile: Colección de Investigaciones Jurídicas de la Universidad Alberto Hurtado, 2004,100 pp.; ARMENTA DEU, Teresa, La prueba ilícita. Un estudio comparado, Madrid: Marcial Pons, 2009, 223 pp.; AMBOS, Kai, "Las prohibiciones de utilización de pruebas en el proceso penal alemán -fundamentación teórica y sistematización", en Política Criminal vol. 4, $\mathrm{N}^{\circ} 7$ (2009), pp. 1-56, en: http://www.politicacriminal.cl/Vol_04/n_07/Vol4N7A1.pdf [visitado el 06.06.2017].
} 
DEL RIO, Carlos. "El principio de trascendencia en relación con el motivo de recurso de nulidad del artículo 373 letra a) del Código Procesal Penal chileno".

derecho individual en diversos supuestos imaginables de ilicitud.

Ahora bien, ¿cómo se expresa el juicio de trascendencia por la Corte Suprema en esta hipótesis? Al revisar la jurisprudencia se advierte que en muchos casos — sino en la mayoría - la Corte piensa en la relevancia potencial de aquella para incidir en lo dispositivo. ${ }^{37}$

El enfoque señalado podría sostenerse en dos tipos de criterios para medir la trascendencia en el caso de la prueba ilícita, que apenas difiere uno de otro. Son los siguientes.

A) Primera fórmula: criterio exógeno. A nuestro juicio consiste en la aplicación de un criterio exógeno a la prueba viciada, que se resuelve en ponderar la motivación del fallo haciendo supresión de la aportación de información objetiva que se introdujo con la prueba viciada. Un test de resistencia de la motivación con base en un examen contrafactual ${ }^{38} \mathrm{o}$ bien de pertinencia objetiva con relación a la motivación en que se sostiene el juicio de hecho.

Un ejemplo prístino de un examen de este tipo nos lo ofrece el razonamiento que hace la Corte Suprema sobre una prueba obtenida con infracción de garantía y que no obstante no tiene trascendencia procesal, precisamente en este caso por carecer de la capacidad de alterar lo resuelto por su falta de conexión con (y por lo tanto de incidencia en) el juicio fáctico incriminatorio. Así, la Corte Suprema, en sentencia de 29 de junio de 2011, señala lo siguiente:

"Que sobre lo preliminar, en el raciocinio sexto del veredicto en revisión (página 5 de la resolución), como otros medios de prueba se hace la síntesis de la transcripción de las interceptaciones telefónicas, que sólo se enumeran desde la primera hasta la decimocuarta, pero sin distinguir la fecha de cada una, con excepción de la inicial que se dice corresponde al seis de julio de dos mil cinco, y donde se escucha la voz de Marina Guerra y una tal Doris que se conciertan para un eventual traspaso de droga en el norte del país. Hasta la conversación que se sindica como cuarta, las mujeres se refieren a un tal David, que será quien intervenga en la entrega y que aquél habría sido detenido en Iquique. Sólo desde la quinta conversación comienzan a hablar de una tal María Eugenia, persona que, en definitiva, fue al norte y realizó la operación de droga y fue detenida junto a la procesada en estos antecedentes y que según refirió la abogada del Ministerio Público- fue reprimida por ese hecho, en fecha pasada.

"Luego de la prueba suministrada por la defensa y que incumbe a algunas de las transcripciones telefónicas y que serían las mismas producidas en el juicio oral, se advierte que sólo se adjuntan las signadas con los números 1 a 4, atinentes a llamadas intervenidas los días seis, siete, siete y trece de julio de dos mil cinco, esto es, aquellas con que se construye la impugnación. Sin embargo, el hecho que se tuvo por establecido y por el que resultó sancionada la [acusada] Guerra Bravo, no se refiere a la intervención del tal David en el suceso, sino que a otro hecho, en que la mujer que

\footnotetext{
${ }^{37}$ Cabe reconocer que parece manifestarse parcialmente en contra STEIN, El conocimiento privado..., cit. nota 18 , pp. 169-184.

38 NAPPI, Il sindacato di legittimità..., cit. nota 20, pp. 199-204, sobre este tipo de examen respecto de los vicios de motivación sobre el juicio fáctico.
} 
Polít. crim. Vol. 13, No 25 (Julio 2018) Art. 9, pp. 322-349.

[http://www.politicacriminal.cl/Vol_13/n_25/Vol13N25A9.pdf]

transportó la droga fue María Eugenia, con la cual se detuvo a Marina Guerra. Es así que las interceptaciones telefónicas de los días seis, siete y trece de julio de dos mil cinco, no tuvieron mérito alguno en la litis para condenar a la enjuiciada, como tampoco para fijar el hecho que se tipificó de tráfico de sustancias estupefacientes, dado que la información lograda de esas escuchas no tiene nada que ver con ese presupuesto fáctico, sino que con otro diverso que no se materializó, porque la hechora y su proveedora Doris se desistieron de emplear a un sujeto de nombre David como correo humano, aparentemente porque supusieron que había sido descubierto como sospechoso.

"En estas condiciones, no es efectivo el reclamo inaugural de la oponente, desde que las escuchas ilícitas no fueron utilizadas para demostrar el hecho punible, como tampoco la intervención de la incriminada en aquél, por cuanto se refieren a circunstancias diferentes de las que se dieron por probadas, lo que pone en evidencia que, de existir la ilegalidad, ella ha carecido de toda trascendencia en lo resuelto." 39

B) Segunda fórmula: criterio de consunción. Aparte de la primera fórmula que queda reflejada en lo expuesto, existe otra que opera como una regla de consunción para medir la trascendencia del vicio, y que remite en concreto al material probatorio introducido al proceso. Se articula en un juicio encaminado a determinar la existencia de una eventual consunción o absorción de la prueba ilícita en otra lícita de igual o mejor calidad, con información de semejante o superior precisión respecto del hecho que está necesitado de prueba $^{40}$. Con este criterio no es que se haga desaparecer la ilicitud de la prueba en cuestión, sino que ella pierde relevancia invalidatoria en tanto la información que porta la fuente de prueba viciada ha ingresado paralelamente al juicio por otras fuentes legítimas.

Un ejemplo de jurisprudencia que acoge esta forma de razonar se halla en la sentencia de 24 de diciembre de 2012, de la Corte Suprema, que afirma:

“(...) es útil consignar que las alegaciones del recurrente carecen de trascendencia, en el sentido que la petición (...) consiste en la exclusión de la primera información obtenida acerca de la menor de edad; empero, en el juicio oral se rindió, además, la prueba consignada en el motivo anterior, de lo cual se infiere que la prueba aportada al juicio y que condujo al convencimiento del tribunal acerca de ese punto surge de diversas fuentes, particularmente testigos y documental, de manera que aun prescindiendo del elemento de cargo que cuestiona la defensa, los otros antecedentes justificativos de dicho elemento objetivo del tipo penal resultan suficientes para fundar la decisión alcanzada, de modo que no le ocasionó ningún perjuicio o daño sustancial a sus

\footnotetext{
${ }^{39} \mathrm{CS}$. Rol N³016-2011. Considerando Cuarto.

${ }^{40}$ Es evidente la conexión de este razonamiento con el que regularmente se utiliza a propósito de la limitación del efecto derivativo de ilicitud, que se suele fundar en el argumento de la fuente independiente, respondiendo finalmente al problema de ilicitud refleja de una fuente de prueba derivada de otra ilícita.

Sin embargo, acá el juicio de trascendencia fundado en lo que denominamos criterio de consunción utiliza el razonamiento no para determinar la ilicitud derivativa de la fuente sino exactamente para fijar la eficacia invalidante de la efectiva introducción al proceso de aquella. Para el problema específico de la prueba ilícita, puede consultarse con provecho: MARTÍNEZ, Eficacia de la prueba ilícita..., cit. nota 23, 237 pp.; HERNÁNDEZ, La exclusión de la prueba ilícita..., cit. nota 23, 100 pp.; ARMENTA, La prueba ilícita ..., cit. nota 23, 223 pp.; AMBOS, "Las prohibiciones de utilización...”, cit. nota 23, pp. 1-56.
} 
DEL RIO, Carlos. "El principio de trascendencia en relación con el motivo de recurso de nulidad del artículo 373 letra a) del Código Procesal Penal chileno".

derechos (...)." ${ }^{41}$

Otro caso es la sentencia de 17 de enero de 2005, de la Corte Suprema, que apunta a propósito del aprovechamiento probatorio de una autoincriminación anómalamente obtenida:

"Que en atención a lo expuesto en los considerandos anteriores, lo que hubiere o no alcanzado a señalar el imputado, carece de toda relevancia, ya que como se ha analizado existe un cúmulo de antecedentes de tal envergadura que permitieron al tribunal dar por acreditada la existencia del hecho punible y de la participación del imputado en dicho ilícito, por lo cual el Tribunal en ningún momento sustentó su decisión en la auto incriminación del imputado." 42

En fin, también en la línea apuntada por ejemplo la Corte Suprema en sentencia de 22 de abril de 2013, respecto de testigos cuya identidad las defensas de los imputados no pudieron conocer y la eventual infracción del debido proceso y otros derechos y garantías fundamentales:

"Que, por otra parte, como se lee de los razonamientos trigésimo octavo, trigésimo noveno y cuadragésimo primero de la sentencia impugnada, la participación de los enjuiciados se tuvo también por establecida con otros antecedentes incriminatorios, los que condujeron a corroborar la imputación del testigo M331A.

"En tales términos, la potestad formulada carece de la trascendencia requerida para provocar la nulidad del juicio y de la sentencia, principio que recoge el artículo 375 del Código Procesal Penal, puesto que la declaración del mentado testigo no fue la única tenida en consideración para fundamentar la convicción condenatoria, lo cual conduce al rechazo de los recursos en torno a esta presunta infracción, que, en caso de existir, carece de influencia sustancial." ${ }^{43}$

\section{Juicio de trascendencia entendido como capacidad para incidir en la decisión (en lo dispositivo) y la presunta superposición con la valoración de la prueba}

El juicio de trascendencia que venimos analizando, que considera la relevancia del vicio denunciado en función de su capacidad para incidir en la decisión de mérito, como la forma de trascendencia que se aplica respecto de los elementos de prueba introducidos o no introducidos al proceso, puede encontrar el reparo consistente en que un concepto como el descrito supondría que la Corte hiciese un escrutinio que implique invadir el ámbito del juicio de valoración probatoria que corresponde al juez de mérito en forma exclusiva ${ }^{44}$. En otras palabras, para esta crítica tal juicio de trascendencia es en realidad un juicio de ponderación probatoria que le estaría vedado al tribunal que conoce del recurso de nulidad.

En nuestra opinión este reproche es erróneo si se tiene en cuenta que esa superposición no existe, puesto que el juicio de trascendencia se halla en un plano anterior y distinto al de la

\footnotetext{
${ }^{41}$ CS. Rol N ${ }^{\circ}$ 7872-2012. Considerando Octavo.

${ }^{42} \mathrm{CS}$. Rol N ${ }^{\circ}$ 5444-2004. Considerando Octavo.

${ }^{43}$ CS. Rol N ${ }^{\circ} 1179-2013$. Considerando Duodécimo.

${ }^{44}$ Sobre este punto conocemos la opinión de la profesora Horvitz Lennon.
} 
Polit. crim. Vol. 13, No 25 (Julio 2018) Art. 9, pp. 322-349.

[http://www.politicacriminal.cl/Vol_13/n_25/Vol13N25A9.pdf]

valoración de la prueba. En efecto, una cosa es valorar la prueba y otra distinta y previa es interpretarla, actividad de la cual no se puede prescindir.

Así una cosa es determinar el contenido objetivo de la prueba: qué ha dicho el testigo o cuál es el contenido del documento. Es decir, fijar el contenido o información que porta la fuente de prueba, y otra sucesiva y diversa es la ponderación como actividad valorativa destinada a determinar si el medio de prueba tiene fuerza racional para acreditar un enunciado de hecho. Lo primero, esto es, la determinación del contenido objetivo que porta una fuente de prueba y su capacidad objetiva para incidir y afectar el juicio de mérito realizado en la sentencia impugnada, son aspectos que pueden ser controlados por el tribunal ad quem vía recurso de nulidad. Y por tal razón puede realizar un control negativo sobre la capacidad informativa de aquella con relación al juicio de hecho, en relación a la garantía de la presunción de inocencia que protege la posición de inocencia del acusado, la cual únicamente cede ante prueba válida y objetivamente incriminatoria. En este paso previo se incardina el juicio de trascendencia cuando el vicio alegado vía recurso de nulidad recae sobre algún elemento de prueba.

La distinción fundamental antes indicada se basa en doctrina procesal muy abonada: así por ejemplo Calamandrei ${ }^{45}{ }^{46}$, Vegas $^{47}$ y Montero. ${ }^{48}$ El primero decía en términos claros lo siguiente:

"La necesidad de ambas operaciones y la diferencia que las separa es manifiesta diariamente en los juicios penales, en los que, durante el examen oral de los testigos, el juez se encuentra de continuo en la necesidad de interpretar qué es lo que quieren decir los testigos, y, al mismo tiempo, en la de valorar la credibilidad de lo que han dicho. Todos los días en las aulas de la justicia penal se presentan testigos, cuyas respuestas constituyen verdaderos enigmas, o porque en el titubeo resultan frases inconexas y fragmentarias, o porque contienen vocablos dialectales y voces de uso popular, que no tienen correspondencia en la lengua ordinaria. ¿Qué ha querido decir el testigo? $\mathrm{He}$ aquí el problema que el juez debe resolver en estos casos; problema bien diverso y no menos importante por cierto que aquel que el juez debe plantearse en segundo lugar, para decidir si el testigo es o no mendaz, es o no reticente, merece o no merece, por el grado de su inteligencia y cultura, ser creído". ${ }^{49}$

\footnotetext{
${ }^{45}$ STEIN, El conocimiento privado..., cit. nota 18, pp. 61 y pp. 169-184, también hace la distinción de la interpretación de la prueba como una parte de la valoración, pero analiza el fenómeno principalmente desde la perspectiva del uso de las máximas de la experiencia y la necesidad de estas para el proceso de subsunción (calificación). Y estima que el control casacional posible siempre se va a situar en el control y censura de la subsunción normativa de los hechos que viene mediada por la utilización de máximas de la experiencia para fijar el contenido (o el sentido) de un medio de prueba, y no propiamente en sede de control sobre la formación del juicio fáctico.

${ }^{46}$ CALAMANDREI, Piero, "Génesis lógica de la sentencia civil", en: CALAMANDREI, Piero, Estudios sobre el proceso civil, Trad.: SENTÍS MELENDO, Santiago, Buenos Aires: Editorial Bibliográfica Argentina, 1945, pp. 377-382.

${ }^{47}$ VEGAS, Presunción de inocencia ..., cit. nota 23, pp. 129-136.

${ }^{48}$ MONTERO, Juan, La prueba en el proceso civil, $5^{\text {a }}$ ed., Cizur Menor: Thomson-Civitas, 2007, pp. 601604.

${ }^{49}$ CALAMANDREI, “Génesis lógica...”, cit. nota 29, pp. 380-381.
} 
DEL RIO, Carlos. "El principio de trascendencia en relación con el motivo de recurso de nulidad del artículo 373 letra a) del Código Procesal Penal chileno".

Nótese que esta distinción es la que en buena medida ha permitido en España el notable desarrollo jurisprudencial del Tribunal Constitucional y del Tribunal Supremo, sobre lo que debe entenderse por control de la existencia de prueba de cargo objetivamente incriminatoria con relación a la garantía de la presunción de inocencia, mediante su control en sede de legitimidad (amparo y casación). ${ }^{50}$ En Derecho italiano la misma distinción teórica es la que parece hacer posible que mediante el art. 606 letra e) del CPPi se pueda controlar lo que se ha denominado travisamento della prova. Vale decir, la posibilidad de controlar la tergiversación de los resultados que derivan de la práctica de un medio de prueba, como consecuencia de un eventual error en la determinación del contenido objetivo de una fuente de prueba introducida al proceso. ${ }^{51}$

\section{Una configuración completa del denominado principio de trascendencia con base en el desarrollo jurisprudencial previamente analizado}

Una configuración íntegra del requisito de trascendencia para el recurso de nulidad penal - con arreglo a todo lo expuesto más arriba - debe basarse, de una parte, en el concepto de indefensión y, de otra, en el de capacidad de la infracción para influir en lo dispositivo del fallo.

Nuestra doctrina especializada ${ }^{52}$, sin embargo, ha tendido a reconocer con claridad solo la primera dimensión, pero no ha reparado de forma explícita en la segunda, no obstante que la jurisprudencia haya venido esbozándola de forma más o menos precisa, tal como se ha analizado. ${ }^{53}$

A nuestro juicio de las cuestiones reflexionadas anteriormente se desprende que el principio de trascendencia — más allá de la literalidad de la fórmula del art. 375- tiene dos manifestaciones claras y complementarias y que deben ser consideradas para tener una configuración completa del principio o regla en el régimen del recurso de nulidad penal.

A) Una primera dimensión del principio de trascendencia es aquella aplicable a los vicios o irregularidades procedimentales que importen infracción a un derecho o garantía que se traduzca en la pérdida o merma concreta de una oportunidad o inmunidad, situación o expectativa procesal, con tal que sea comprobable y que en consecuencia pueda considerarse un detrimento concreto al derecho de defensa. Vale decir, en este caso la trascendencia es la concreta indefensión para la parte afectada. ${ }^{54}$

\footnotetext{
${ }^{50}$ El estudio más profundo sobre esta cuestión es el de VEGAS, Presunción de inocencia..., cit. nota 23, 414 pp.

${ }^{51}$ En este sentido, FOLLIERI, Antonella, “Comento Articolo 606”, en: BRONZO, Pasquale (Coord.), Codice di Procedura Penale, Milano: Giuffrè, pp. 461-510, 2008, pp. 490-491, y NAPPI, Il sindacato di legittimità..., cit. nota 20, pp. 196-197.

52 Vid. OTERO, La nulidad procesal..., cit. nota 9, pp. 148-149 y 175-180; SALAS, Los incidentes..., cit. nota 10, pp. 215 y ss; HORVITZ / LÓPEZ Derecho procesal penal, cit. nota 3, pp. 392-393.

${ }^{53}$ Otras veces la doctrina (por ejemplo, RIETOURD, El recurso de nulidad..., cit. nota 4, pp. 42-44) y cierta jurisprudencia ha creído encontrar el principio de trascendencia en el artículo 373 letra a), cuando este refiere el carácter sustancial de la lesión a la garantía afectada, pero no ha podido precisar qué cosa se va a entender con exactitud por esto.

${ }^{54}$ Nótese que tal dimensión de la nulidad, la dogmática procesal clásica la ha sentado de forma invariable. Un
} 
Polít. crim. Vol. 13, Nº 25 (Julio 2018) Art. 9, pp. 322-349.

[http://www.politicacriminal.cl/Vol_13/n_25/Vol13N25A9.pdf]

En esta faceta la trascendencia tiene por concepto clave la indefensión material ${ }^{55}$ que ha de producirse como resultado del vicio procesal que lesiona un derecho o garantía ${ }^{56}$, consecuencia ineludible de la concepción de la nulidad procesal como una técnica protectora del derecho de defensa ${ }^{57}$, lo cual se encuentra especialmente reforzado en el proceso penal por razones que entroncan con los importantes condicionamientos normativos de este proceso. Así las cosas el juicio de trascendencia de esta forma considerado guardaría exacta consonancia con el fin que anima a la institución de la nulidad procesal con arreglo a la forma en que últimamente ha venido concebida en la dogmática y la jurisprudencia más actualizadas.

estudio muy influyente en el procesalismo chileno sobre el particular es el de ALSINA, Hugo, Las nulidades en el proceso civil. Concepto y función de las formas procesales, Lima: ARA editores, 2006, pp. 65-66, que al respecto apuntó "La misión de la nulidad, en efecto, no es propiamente asegurar la observancia de las formas procesales, sino el cumplimiento de los fines a ellas confiados por la ley. Las formas son el medio o el instrumento de que el legislador se vale para hacer efectiva la garantía constitucional de la defensa en juicio, lo cual constituye el fundamento de los llamados Derechos procesales de las partes. En cualquier supuesto en que esa garantía aparezca violada, aunque no haya texto expreso en la ley, la declaración de nulidad se impone; en cambio, no obstante, la existencia de un texto expreso, la nulidad es improcedente si a pesar del defecto que el acto contiene, el fin propuesto ha sido alcanzado. Tal es, en último análisis, el sentido de la expresión pas de nullité sans grief que el legislador francés ha terminado por reincorporar a su Código y que en el nuevo Código italiano establece como base de su sistema. La fórmula sería, pues, la siguiente: donde hay indefensión, hay nulidad; si no hay indefensión, no hay nulidad. Necesariamente debe entonces confiarse al juez la apreciación de las situaciones de hecho, ya que por su complejidad sería imposible preverlas en la ley. El juez debe ser exigente en el respeto de la garantía de la defensa en juicio, pero prudente en la declaración de la nulidad y en caso de duda decidirse por ésta, pues es la mejor manera de asegurar el respeto de aquella."

${ }^{55}$ Que la trascendencia del vicio se traduzca en la producción de indefensión es una cosa que los autores clásicos siempre tuvieron claro: por todos, COUTURE, Eduardo, Fundamentos de Derecho procesal civil, Buenos Aires: Depalma, 1993, pp. 390-391. También MORÓN, La nulidad..., cit., nota 14, pp. 89 y ss. y pp. 189-190. En términos más generales resultan estimulantes las reflexiones sobre las formas procesales y su relación con la libertad, la exclusión del arbitrio y la garantización de la defensa judicial que hace el propio CHIOVENDA, Giusseppe, "Las formas en la defensa judicial del Derecho", en CHIOVENDA, Giusseppe, Ensayos de Derecho procesal civil, t. II, Trad.: SENTÍS MELENDO, Santiago, Buenos Aires: EJEA, 1949, pp. 123 y ss, y específicamente, p. 126; y en la línea chiovendiana ALSINA, Las nulidades...., cit. nota 37, pp. $15-29$ y 49 y ss.

En Chile, siguiendo a Couture, TAVOLARI OLIVEROS, Raúl, "La nulidad procesal en el Derecho actual", en: TAVOLARI OLIVEROS, Raúl, El proceso en acción, Santiago: Libromar, 2000, 712 pp., pp. 264-266, y CARRASCO, "La nulidad procesal...", cit. nota 13, pp. 49-84. También en una línea semejante MOSQUERA / MATURANA, Los recursos procesales, cit. nota 3, p. 338.

${ }^{56}$ Cabe observar que el concepto de indefensión tiene una larga tradición en el Derecho comparado. Así por ejemplo en Derecho español el desarrollo de este concepto con apoyatura en el artículo 24.1 de la Constitucional española, se remonta a la sentencia del TRIBUNAL CONSTITUCIONAL (ESPAÑA). 4 de abril de 1984. Rol N 48/1984 y luego desarrollado en TRIBUNAL CONSTITUCIONAL (ESPAÑA). 23 de abril de 1986. Rol No 48/1986. Básicamente se sostiene que para que una «irregularidad procesal o infracción de las normas de procedimiento alcance relevancia debe producir un perjuicio real y efectivo en las posibilidades de defensa». Vid. BELLIDO PENADÉS, Rafael: "Motivos del recurso extraordinario por infracción procesal (II)", en: AA.VV.: El recurso extraordinario por infracción procesal, Madrid: La Ley, pp. 205-245, 2013, pp. 212-213. También BONET NAVARRO, José, Casación penal e infracción de precepto constitucional, Cizur Menor: Aranzadi, 2000, pp. 72 y ss, para el proceso penal español, con el detalle de casos en que se valora la concurrencia de indefensión en supuestos específicos.

${ }^{57}$ En nuestro medio el estudio más preciso sobre el particular es el del profesor CARRASCO, "La nulidad procesal...", cit. nota 13, pp. 49-84, y específicamente pp. 67 y ss. 
DEL RIO, Carlos. "El principio de trascendencia en relación con el motivo de recurso de nulidad del artículo 373 letra a) del Código Procesal Penal chileno".

B) La segunda dimensión se hace cargo de un supuesto bien distinto, esto es, cuando el error in procedendo está referido a la formación del acervo probatorio, sea por exceso o por defecto, en cuyo caso la trascendencia de aquel no puede medirse sino por su poder para llegar a incidir en el juicio fáctico, medida en función de su capacidad para introducir información al proceso, en los términos previamente desarrollados.

De acuerdo a lo dicho un concepto global de ambos aspectos bien podría ser expresado del siguiente modo: el principio de trascendencia se traduce en que los vicios que importen infracción a un derecho o garantía, supongan la pérdida o merma concreta de una oportunidad o inmunidad, situación o expectativa procesal, con tal que sea comprobable y que en consecuencia pueda considerarse un detrimento concreto al derecho de defensa; o bien, para el caso que los vicios refieran a la formación del mérito fáctico del proceso, en la capacidad para influir en lo dispositivo del fallo.

Ciertamente hay un paralelismo con el concepto de trascendencia aplicable para el recurso de casación en la forma, que en el artículo 768 inciso penúltimo del Código de Procedimiento Civil, establece que el "tribunal podrá desestimar el recurso de casación en la forma, si de los antecedentes aparece de manifiesto que el recurrente no ha sufrido un perjuicio reparable sólo con la invalidación del fallo o cuando el vicio no ha influido en lo dispositivo del mismo".

También en la casación en la forma del proceso civil, el concepto de trascendencia es complejo y no se remite únicamente al supuesto de indefensión. Lo mismo que en el recurso de nulidad, la razón estriba en los distintos tipos que aglutina el instituto: vicios que inciden en una inejecución de una norma procesal que tiene relación con la formación del proceso, y otros vicios que - siendo procesales - se verifican en la forma o actividad de enjuiciamiento, como típicamente la sentencia incongruente o aquella dada contra otra pasada con autoridad de cosa juzgada o la que contiene decisiones contradictorias. Obsérvese que en este caso, la casación formal recoge hipótesis de errores que importan el quebranto de un mandato que regula la actividad de enjuiciamiento, y no exactamente el procedimiento $^{58}{ }_{-}^{59}$, y por eso mismo el precepto sobre la trascendencia del vicio (inciso penúltimo del art. $768 \mathrm{CPC}$ ) exige alternativamente o bien que el perjuicio sea la indefensión o bien que el error influya en lo dispositivo del fallo.

Con todo, la fórmula para expresar el requisito de la trascendencia es solo parcialmente correcta, dado que no todos los vicios que se producen o materializan con el pronunciamiento de la sentencia pueden pesquisarse necesariamente en lo resolutivo. Así,

\footnotetext{
${ }^{58}$ La doctrina siempre ha tenido claro este punto: vid. por ejemplo CALAMANDREI, La casación civil, cit. nota $1, t$. I., vol. I, pp. 362 y ss.; y críticamente NIEVA, "La enunciación...”, cit. nota 2, pp. 84-85. En nuestro medio también CORTEZ, El recurso de nulidad, cit. nota 2, pp. 143-144.

${ }^{59}$ Con lo indicado no se quiere decir sin embargo que estos motivos in iudicando, que se resuelven en la inejecución de normas que determinan la forma y extensión del enjuiciamiento sean de la misma naturaleza que los motivos in iudicando propios de la casación en el fondo. En este recurso de fondo el error o la inobservancia está siempre referida a la norma material que se utiliza o debe utilizarse, y no a normas que regulan la actividad de enjuiciamiento o la extensión y límites de los poderes de decisión del juez. Es esta la razón por la cual se suele hacer referencia a los errores in iudicando in iure que son los propios de la casación de fondo o por infracción de ley.
} 
Polit. crim. Vol. 13, No 25 (Julio 2018) Art. 9, pp. 322-349.

[http://www.politicacriminal.cl/Vol_13/n_25/Vol13N25A9.pdf]

el que se refiere a la sentencia que se pronuncia con omisión de los requisitos del artículo 170 del CPC, cuando por ejemplo aparece vinculado al numeral 4 de este precepto, vale decir, a la falta de motivación de hecho del fallo ${ }^{60}$, caso en el cual no hay examen del recurso que permita pesquisar la efectiva influencia en el contenido del dispositivo como no sea haciendo una ponderación completa del mérito probatorio de la causa, lo que ciertamente excede los límites del examen posible en el recurso de casación formal. En este caso el examen no puede hacerse sino — de nuevo - sobre la capacidad que pudo llegar a tener la omisión en relación con el contenido probatorio objetivo que no fue ponderado. La capacidad que aquella información introducida al proceso tenía para afectar el juicio de hecho. ${ }^{61}$

Así las cosas, la trascendencia se traduce en un juicio de decisividad con la orientación apuntada por Nappi ${ }^{62}$ para el sistema italiano. Este, en opinión del autor citado, se resuelve en un juicio contrafactual, vale decir, en un juicio en el cual se verifica si el hecho o prueba desatendidos, sobre el cual se ha controvertido, aun con la supresión de aquellos es posible sostener que la justificación es suficiente para respaldar el juicio de hecho formulado en la sentencia o si en cambio el mismo decae y queda carente de sostén suficiente. Por eso apunta $^{63}$ " $[\mathrm{e}] \mathrm{n}$ consecuencia esta prospectiva debe permitir excluir también de un vicio de motivación que se refiera a un hecho controvertido, ya que puede darse un hecho que, siendo secundario, resulte controvertido y ello no obstante no decisivo. Y en este caso la decisividad es usada todavía como un criterio de valoración de la idoneidad de la justificación; una valoración conducida mediante un juicio contrafactual que verifica si la motivación resista incluso prescindiendo del hecho controvertido objeto de inválida motivación o bien incluso considerando el hecho controvertido omitido".

\section{Conclusión}

Es evidente que el problema normativo, tanto por la redacción del art. 373 letra a) como por lo dispuesto en el art. $375 \mathrm{y}$ el resto de preceptos tocantes al recurso de nulidad, existe y es relevante. Muestra bien patente de ello es que no solo ha sido una cuestión discutida por la doctrina, sino además - y de forma especial - por la jurisprudencia de la Corte Suprema, como se demostró. En efecto, esta ha encarado el problema desde distintos puntos de vistas, los cuales se han examinado en sus distintos alcances.

De lo anterior se desprende el principal hallazgo de este estudio, que puede dividirse en dos dimensiones. Primero, la aclaración de cuál sea el mejor régimen jurídico con relación al problema planteado, armónico con el tipo de motivo al que se aplica, con su naturaleza jurídica, en tanto es evidente que la trascendencia del vicio que se denuncia ha de ajustarse a la naturaleza del vicio mismo que se censura, lo que además queda reflejado en el diseño del motivo.

\footnotetext{
60 Tal como hemos apuntado, este tipo específico de motivo se aproxima a lo que se ha denominado como error in iudicando in facti. Vid. CALAMANDREI, La casación civil, cit. nota 1, vol. III, pp. 306-308.

${ }^{61}$ Traducción libre de NAPPI, Il sindacato di legittimità..., cit. nota 20, pp. 200 y ss, respecto del sistema italiano en que se sostiene la misma idea bajo el concepto de decisividad del vicio de motivación fáctica.

${ }^{62}$ NAPPI, Il sindacato di legittimità..., cit. nota 20, pp. 203-204.

${ }^{63}$ NAPPI, Il sindacato di legittimità..., cit. nota 20, pp. 203-204.
} 
DEL RIO, Carlos. "El principio de trascendencia en relación con el motivo de recurso de nulidad del artículo 373 letra a) del Código Procesal Penal chileno".

En segundo término, constatado lo anterior, la importancia de intentar una configuración del requisito de trascendencia en función de los casos o hipótesis que finalmente pueden ser planteados a través del motivo. Así, creemos haber demostrado que el juicio de trascendencia, vale decir, el juicio de verificación jurisdiccional que se debe hacer puede adoptar dos formas diferenciadas, las que responden a las peculiaridades del vicio objeto del recurso, en los términos previamente desarrollados. 
Polít. crim. Vol. 13, № 25 (Julio 2018) Art. 9, pp. 322-349.

[http://www.politicacriminal.cl/Vol_13/n_25/Vol13N25A9.pdf]

\section{Bibliografía}

ALSINA, Hugo, Las nulidades en el proceso civil. Concepto y función de las formas procesales, Lima: ARA editores, 2006.

AMBOS, Kai, "Las prohibiciones de utilización de pruebas en el proceso penal alemán fundamentación teórica y sistematización", en Política Criminal vol. 4, Nº 7 (2009), pp. 1-56, en: http://www.politicacriminal.cl/Vol_04/n_07/Vol4N7A1.pdf [visitado el 06.06.2017].

ARMENTA, Teresa, La prueba ilícita. Un estudio comparado, Madrid: Marcial Pons, 2009.

BELLIDO PENADÉS, Rafael: "Motivos del recurso extraordinario por infracción procesal (II)", en: AA.VV.: El recurso extraordinario por infracción procesal, Madrid: La Ley, pp. 205-245, 2013.

BONET NAVARRO, José, Casación penal e infracción de precepto constitucional, Cizur Menor: Aranzadi, 2000.

CALAMANDREI, Piero, "Génesis lógica de la sentencia civil", en: CALAMANDREI, Piero Estudios sobre el proceso civil, Trad.: SENTÍS MELENDO, Santiago, Buenos Aires: Editorial Bibliográfica Argentina, 1945, pp. 377-382.

CALAMANDREI, Piero, La casación civil, t. I, vol. I, Trad.: SENTÍS, Santiago, Buenos Aires: Editorial Bibliográfica de Argentina, 1945.

CARRASCO POBLETE, Jaime, "La nulidad procesal como técnica protectora de los derechos y garantías de las partes en el Derecho procesal chileno", Revista de Derecho Universidad Católica del Norte, n. 18.1 (2011), pp. 49-84, p. 69, en: http://revistaderecho.ucn.cl/index.php/rducn/article/view/115/115 [visitado el 06.06.2017].

CHIOVENDA, Giusseppe, "Las formas en la defensa judicial del Derecho", en CHIOVENDA, Giusseppe, Ensayos de Derecho procesal civil, t. II, Trad.: SENTÍS MELENDO, Santiago, Buenos Aires: EJEA, 1949, pp. 123-154.

CORTEZ MATCOVICH, Gonzalo, El recurso de nulidad, Santiago: LexisNexis, 2006.

COUTURE, Eduardo, Fundamentos de Derecho procesal civil, Buenos Aires: Depalma, 1993.

DEL RÍO FERRETTI, Carlos, El derecho al recurso y el recurso de nulidad penal, Santiago de Chile: Thomson Reuters, 2014. 
DEL RIO, Carlos. "El principio de trascendencia en relación con el motivo de recurso de nulidad del artículo 373 letra a) del Código Procesal Penal chileno".

DUCE JULIO, Mauricio; RIEGO RAMÍREZ, Cristián, Proceso penal, Santiago de Chile: Editorial Jurídica de Chile, 2007.

FONTANA, Filippo: "Commento Articolo 177" en: CORSO, Piermaria (Editor): Commento al Codice di procedura penale, Piacenza: Casa Editrice LaTribuna, 2005, pp. 527-532.

FOLLIERI, Antonella, "Comento Articolo 606”, en: BRONZO, Pasquale (Coord.), Codice di Procedura Penale, Milano: Giuffrè, 2008, pp. 461-510.

GAROFOLI, Vincenzo, Istituzione di Diritto processuale, Milano: Giuffrè, 2006.

HERNÁNDEZ BASUALTO, Héctor, La exclusión de la prueba ilícita en el nuevo proceso penal chileno, Santiago de Chile: Colección de Investigaciones Jurídicas de la Universidad Alberto Hurtado, 2004.

HORVITZ LENNON, María Inés; LÓPEZ MASLE, Julián, Derecho procesal penal, $t$. II, Santiago de Chile: Editorial Jurídica de Chile, 2005.

MARTÍNEZ GARCÍA, Elena, Eficacia de la prueba ilícita en el proceso penal, Valencia: Tirant lo Blanch, 2003.

MONTERO, Juan, La prueba en el proceso civil, $5^{a}$ ed., Cizur Menor: Thomson-Civitas, 2007.

MORÓN PALOMINO, Manuel, La nulidad en el proceso civil español, Barcelona: Editorial AHR, 1957.

MOSQUERA RUIZ, Mario; MATURANA MIQUEL, Cristián, Los recursos procesales, Santiago de Chile: Editorial Jurídica de Chile, 2010.

NAPPI, Aniello, Il sindacato di legittimità nei giudizi civili e penali di cassazione, Torino: Giappichelli, 2006.

NIEVA, Jordi "La enunciación de los motivos de casación en las leyes procesales", en: NIEVA, Jordi, El recurso de casación, Santiago de Chile: Abeledo Perrot, 2010, pp. 75 y ss.

OTERO LATHROP, Miguel, La nulidad procesal civil, penal, y de derecho público, $2^{a}$ Ed., Santiago de Chile: Editorial Jurídica de Chile, 2010.

RIETOURD ALVARADO, Andrés, El recurso de nulidad en el nuevo proceso penal, Santiago de Chile: Editorial Jurídica de Chile, 2007.

ROSENBERG, Leo, Tratado de Derecho procesal civil, t. I, Trad.: ROMERA VERA, Ángela, Buenos Aires: Ejea, 1955. 
Polit. crim. Vol. 13, No 25 (Julio 2018) Art. 9, pp. 322-349.

[http://www.politicacriminal.cl/Vol_13/n_25/Vol13N25A9.pdf]

SALAS VIVALDI, Julio, Los incidentes y en especial el de nulidad en el proceso civil, penal y laboral, $7^{\mathrm{a}}$ Ed., Santiago de Chile: Editorial Jurídica de Chile, 2000.

STEIN, Friedrich, El conocimiento privado del juez, Trad.: DE LA OLIVA SANTOS, Andrés, Pamplona: Ediciones Universidad de Navarra, 1973.

TAVOLARI OLIVEROS, Raúl, "La nulidad procesal en el Derecho actual", en: TAVOLARI OLIVEROS, Raúl, El proceso en acción, Santiago: Libromar, 2000, pp. pp. 264-266.

TONINI, Paolo, Lineamenti di Diritto processuale penale, $3^{\mathrm{a}}$ Ed., Milano: Giuffrè, 2005.

VEGAS TORRES, Jaime, Presunción de inocencia y prueba en el proceso penal, Madrid: La Ley, 1993. 